\title{
The south Asian cataract management study
}

\author{
I. The first 662 cataract surgeries: a preliminary report
}

The South Asian Cataract Management Study Group*

\begin{abstract}
Aims-The first 662 cases of a multicentre randomised clinical trial of intracapsular cataract extraction (ICCE) with and without implantation of a four point multiflex (Cilco Kelman Choyce Modification) anterior chamber intraocular lens (AC IOL) were studied after 6 weeks to compare frequency of surgical complications, short term clinical outcomes, and corneal endothelial cell loss between groups.

Methods-Randomisation was performed after screening for predetermined inclusion and exclusion criteria. Demographics, visual acuities, intraocular pressures, and corneal endothelium cell data were recorded preoperatively and at 6 weeks. Details of surgical procedure, complications, and postoperative adverse reactions were recorded. Monitoring of the study was secured by a standardised image documentation procedure on all patients using the IMAGEnet digital imaging system. Analysis of corneal endothelial cell images was done using the CELL SOFT software analysis program.
\end{abstract}

Results-343 patients were randomised to IOL and 319 to no IOL. Twelve IOL implantations (3.5\%) were aborted because of complications. A complication was reported in $103(15.6 \%)$ of the surgical procedures (IOL $=16.9 \%$, no $I O L=14.1 \%$, $\mathbf{p}=0.37$ ). The most frequent complication observed was vitreous loss followed by plain capsular rupture, unplanned ECCE, and iris dialysis. Mean corneal endothelial cell loss 6 weeks after surgery was $17 \cdot 2 \%$ (SD $13 \cdot 1 \%$ ) in the total study population (IOL $=18 \cdot 5 \%$ no IOL $=16 \cdot 1 \%, p=0 \cdot 05)$. The postoperative complications registered until 6 week follow up were significantly higher in the IOL group (IOL $=6.9 \%$, no IOL $=2.6 \%, p=0.02$ ), mainly due to mild to moderate iritis needing prolonged use of steroids. Eighty nine per cent of the patients had a best corrected visual acuity of $6 / 18$ or better. There was no significant difference in visual outcome between study groups.

Conclusions-The implantation of a multiflex AC IOL in primary ICCE surgery in the centres of this study did not increase the risk of surgical complications or short term sight threatening adverse clinical outcomes compared with ICCE without lens. Comparisons of corneal endothelial cell loss after 6 weeks between study groups showed no clinically significant difference. The difference in mean cell loss between groups was statistically significant.

(Br f Ophthalmol 1995; 79: 1029-1035)

In the past decade extracapsular cataract extraction (ECCE) with posterior chamber intraocular lens (PC IOL) has been established as the standard approach to visual rehabilitation of surgical aphakia in industrialised nations. For developing countries, however, the introduction of intraocular lenses with ECCE has created a socioeconomic and surgical dilemma. ${ }^{1-4}$ Clinical studies have revealed a varying incidence of posterior capsular opacification (PCO) approaching 50\% in some investigations. ${ }^{5}$ If ECCE PC IOL becomes the treatment of choice in the developing countries and if access to YAG laser capsulotomy does not improve then PCO alone may rank as the second most common cause of visual loss, second only to the primary cataract itself. In India, where some 1.4 million cataract operations are performed annually, 100 000-200 000 cases may need YAG laser capsulotomy already within the first 3 months after surgery. ${ }^{6}$ Cystoid macular oedema is recognised as a complication of capsulotomy ${ }^{78}$ and a recent study on the long term effect of YAG capsulotomy suggests that this procedure may increase the risk of retinal detachment. ${ }^{9}$

The World Health Organisation (WHO) estimates the total number of blind worldwide to be 38 million with cataract, representing $41.8 \%$, being the most important cause of blindness in all developing countries. ${ }^{1011}$ The low cost technique of intracapsular cataract extraction (ICCE) with (+10 D) aphakic spectacle correction, has been the standard approach to cataract surgery giving benefit to millions of cataract blind in the developing countries. However, with the introduction of the intraocular lens and the realisation of its superiority in visual restoration, there is now an increasing demand and pressure to adopt IOLs.

Data from the Center for Intraocular Lens Research, Medical University of South Carolina ${ }^{12-16}$ indicate clearly that the severe complications reported on the use of anterior chamber intraocular lenses (AC IOLs) were related to the bad quality and design of the lenses.

Reports have shown that the new generation of AC IOLs is safe and effective in secondary cataract surgery and IOL exchange ${ }^{1718}$ and recent reports show that ICCE with AC IOLs 
Table 1 Surgical routines

\begin{tabular}{|c|c|c|c|}
\hline Treatment & Centre 1 & Centre2 & Centre 3 \\
\hline Topical antibiotics & $\begin{array}{l}\text { Chloramphenicol } 6 \text { hourly } 24 \\
\text { hours before surgery }\end{array}$ & $\begin{array}{l}\text { Chloramphenicol } 6 \text { hourly } 72 \\
\text { hours before surgery }\end{array}$ & None \\
\hline $\begin{array}{l}\text { Anaesthesia } \\
\text { Retrobulbar } \\
\text { Facial block } \\
\text { Pressure reduction } \\
\text { Sutures (corneoscleral) } \\
\text { Subconjunctival injections }\end{array}$ & $\begin{array}{l}\text { Xylocaine } 2 \mathrm{ml} \\
\text { Xylocaine } 5 \mathrm{ml} \\
\text { Weight balance } 5 \text {-10 minutes } \\
5-7(9 / 0-10 / 0 \mathrm{mono} \text {-filament) } \\
\text { Gentamicin } 0.5 \mathrm{ml}(20 \mathrm{mg}) \text {, } \\
\text { Dexamethasone } 0.5 \mathrm{ml} \\
(2 \mathrm{mg})\end{array}$ & $\begin{array}{l}\text { Xylocaine } 3.5 \mathrm{ml} \\
\text { Xylocaine } 1.5 \mathrm{ml} \\
\text { Weight balance } 5 \text { minutes } \\
5 \text { (9/0-10/0 mono-filament) } \\
\text { Gentamicin } 0.5 \mathrm{ml}(20 \mathrm{mg}) \text {, } \\
\text { Dexamethasone } 0.5 \mathrm{ml} \\
(2 \mathrm{mg})\end{array}$ & $\begin{array}{l}\text { Xylocaine }{ }^{\star} 6 \mathrm{ml} \\
\text { Xylocaine }{ }^{\star} 3 \mathrm{ml} \\
\text { Pinky weight } 20 \text { minutes } \\
7(10 / 0 \text { mono-filament }) \\
\text { Gentamicin } 0.5 \mathrm{ml}(20 \mathrm{mg}) \text {, } \\
\text { Dexamethasone } 0.5 \mathrm{ml} \\
(2 \mathrm{mg})\end{array}$ \\
\hline
\end{tabular}

$\star+2 \%$ adrenaline with Hylase.

gives comparable results to ECCE with implantation of PC IOL in primary cataract surgery. 1920

From south Asia data are available on the outcomes of ICCE without implantation of IOL but no study to date has reported on outcomes of ICCE with the modern generation AC IOL lenses. The main purpose of this study was to compare the results of ICCE using a modern AC IOL implant with ICCE with aphakic spectacle correction in clinical settings of south Asia. The main outcome is visual acuity after 2 years of follow up. This paper presents surgical complications and short term outcomes of the first 662 surgical procedures.

\section{Patients and methods}

\section{STUDY DESIGN}

The South Asian Cataract Management Study (SACMS) is a multicentre randomised controlled clinical trial. Patients are assigned to two treatment groups: (1) ICCE with implantation of a multiflex four point fixation AC IOL (referred to as 'IOL group'). (2) ICCE and no IOL implantation (referred to as 'no IOL group').

The participating centres were: the Department of Ophthalmology, Institute of Medicine, Tribhuvan University Teaching Hospital, Kathmandu in collaboration with the Mid-Western Eye Care Programme, Nepal Netra Jyothi Sangh, Nepal (centre 1); the Institute of Community, Ophthalmology, University of Chittagong and the Chittagong Eye Infirmary and Training Complex, Bangladesh National Society for the Blind, Bangladesh (centre 2); the LV Prasad Eye Institute, Hyderabad, India (centre 3). All centres followed the same protocol for patient inclusion and follow up. Data were collected preoperatively at inclusion, discharge, 6 weeks, 12 months, and a final evaluation at 24

Table 2 Preoperative mean (SD) of age, intraocular pressure, and corneal endothelial cell density by centre

\begin{tabular}{|c|c|c|c|c|c|}
\hline & $\begin{array}{l}\text { Centre 1 } \\
(n=229)\end{array}$ & $\begin{array}{l}\text { Centre } 2 \\
(n=300)\end{array}$ & $\begin{array}{l}\text { Centre 3 } \\
(n=133)\end{array}$ & $\underset{(n=662)}{A l l}$ & $\stackrel{p}{\text { Value }}$ \\
\hline $\begin{array}{l}\text { Age (years) } \\
\text { Intraocular pressure (mm }\end{array}$ & $\mathrm{Hg}^{60(8 \cdot 5)}$ & $60(7 \cdot 7)$ & $61(7 \cdot 1)$ & $60(7 \cdot 9)$ & 0.40 \\
\hline $\begin{array}{l}\text { Right eye } \\
\text { Left eye } \\
\text { Inclusion eye } \\
\text { Cell density (cells } / \mathrm{mm}^{2} \text { ) }\end{array}$ & $\begin{array}{r}14.9(2.5) \\
14.8(2.4) \\
14.9(2.5) \\
2708(356)\end{array}$ & $\begin{array}{c}16.1(2 \cdot 2) \\
16.0(2 \cdot 3) \\
16.0(2 \cdot 2) \\
2795(330)\end{array}$ & $\begin{array}{r}13.6(2 \cdot 7) \\
13.6(2 \cdot 7) \\
13.5(2 \cdot 8) \\
2721(413)\end{array}$ & $\begin{array}{r}15 \cdot 1(2 \cdot 6) \\
15 \cdot 2(2 \cdot 6) \\
15 \cdot 1(2 \cdot 6) \\
2750(359)\end{array}$ & $\begin{array}{l}<0.01 \\
<0.01 \\
<0.01 \\
>0.5\end{array}$ \\
\hline
\end{tabular}

^Analysis of variance (ANOVA) was used for age and IOP; Kruskal-Wallis test for cell density. months after surgery. In Nepal the study was conducted in a rural eye hospital of the mid western development region. In India and Bangladesh the participating institutions were national/regional surgical training centres.

\section{PATIENT RECRUITMENT AND ELIGIBILITY}

All patients between 40 and 75 years were eligible if they had visual acuity equal to and less than $6 / 60$ or minimum of perception of light in three out of four quadrants of visual fields in both eyes owing to senile cataract grade $2 \mathrm{~B}$ and 3 according to Mehra and Minassian. ${ }^{21}$ The patients were recruited either through peripheral screening camps or outpatient clinics.

\section{EXCLUSION CRITERIA}

Excluded were patients with glaucoma and or intraocular pressure $>26 \mathrm{~mm} \mathrm{Hg}$; acute or chronic corneal disease; shallow anterior chamber (evidence of iridocorneal contact); chronic iris disease or iris defect; anterior synechiae, traumatic, or complicated cataract; suspected non-lenticular axial high myopia; one eyed and or aphakic; diabetic retinopathy; chronic or severe systemic disease likely to cause death within 3 years.

SAMPLE SIZE AND RANDOMISATION PROCEDURE The study was designed with a power of $90 \%$ $(\beta=0 \cdot 10)$ to detect a twofold difference of poor visual outcome (visual acuity less than $6 / 18$ with best possible correction) using a significance level of $5 \%$. It was assumed that the proportion of patients with poor outcome at the end of the study in traditional ICCE with aphakic spectacle correction was $5 \%$. Assuming a $10 \%$ loss of cases because of death, 1500 cases were included in the study. Block randomisation was done by using computer generated random numbers. After a patient was included in the study, a sealed envelope was opened with instruction of lens implantation or no lens implantation.

\section{SURGERY}

Cilco single piece Kelman Multiflex MT/MTA anterior chamber lenses were used. Determination of IOL power was based on clinical judgment in centre 1 and A-scan in the other centres. The surgical routines are described in Table 1. All surgery was performed with the assistance of an operating microscope with 
Table 3 Preoperative mean (SD) of age, intraocular pressure, and cell density by study groups

\begin{tabular}{|c|c|c|c|c|c|c|c|}
\hline & \multicolumn{2}{|c|}{ Study $(n=662)$} & \multicolumn{2}{|c|}{$\operatorname{IOL}(n=343)$} & \multicolumn{2}{|c|}{ No IOL $(n=319)$} & \multirow{2}{*}{$\stackrel{p}{\text { Value }}$} \\
\hline & Mean (SD) & Range & Mean (SD) & Range & Mean (SD) & Range & \\
\hline $\begin{array}{l}\text { Age } \\
\text { Intraocular pressure }\left(\mathrm{mm} \mathrm{Hg}^{\mathrm{H}}\right) \\
\left.\text { Cell density (cells } / \mathrm{mm}^{2}\right)\end{array}$ & $\begin{array}{c}60(7 \cdot 9) \\
15(2 \cdot 6) \\
2750(359)\end{array}$ & $\begin{array}{c}40-75 \\
6-20 \\
1408-3629\end{array}$ & $\begin{array}{r}61(8 \cdot 0) \\
15(2 \cdot 6) \\
2754(361)\end{array}$ & $\begin{array}{c}40-75 \\
6-20 \\
1408-3567\end{array}$ & $\begin{array}{r}60(7 \cdot 8) \\
15(2 \cdot 7) \\
2749(341)\end{array}$ & $\begin{array}{c}40-75 \\
8-20 \\
1478-3629\end{array}$ & $\begin{array}{l}0 \cdot 19 \\
0 \cdot 85 \\
0.95\end{array}$ \\
\hline
\end{tabular}

^Student's $t$ test.

4-10× magnification. It was recommended that the surgeon should have performed at least 100 ICCE and at least $20 \mathrm{AC}$ IOL implantations before being accepted as a participating surgeon in the study. Before the commencement of the study surgeons from two centres participated in a 5 day clinical workshop where surgical techniques of AC IOL insertion after ICCE were demonstrated and practised. The surgeons were recommended to keep surgical manipulation and the use of intraocular fluids and viscoelastics to a minimum. All surgeons use the technique of ab externo corneoscleral section and cryoassisted extraction of the crystalline lens.

\section{DOCUMENTATION}

Basic documentation included detailed history, determination of visual acuity, slit-lamp biomicroscopy, applanation tonometry, and fundus examination. Details of surgical procedure, immediate postoperative complications, and status at discharge were recorded on all cases. Postoperative events including surgically related complications and reactions needing surgical or medical intervention were recorded on separate treatment cards. Intraocular pressures were registered with calibrated HaagStreit applanation tonometers.

Table 4 Surgical procedure by study groups

\begin{tabular}{|c|c|c|c|c|}
\hline & $\begin{array}{l}\text { Study total } \\
(n=662)(\%)\end{array}$ & $\begin{array}{l}I O L \\
(n=343)(\%)\end{array}$ & $\begin{array}{l}\text { No IOL } \\
(n=319)(\%)\end{array}$ & $\stackrel{p}{\text { Value }}$ \\
\hline Anaesthesia & & & & $0.46^{\star}$ \\
\hline $\begin{array}{l}\text { Retrobulbar block } \\
\text { Peribulbar block }\end{array}$ & $\begin{array}{l}529(79.9) \\
133(20 \cdot 1)\end{array}$ & $\begin{array}{r}272(79 \cdot 3) \\
71(20 \cdot 7)\end{array}$ & $\begin{array}{r}257(80 \cdot 6) \\
62(19 \cdot 4)\end{array}$ & \\
\hline IOP reduction & & & & $0.96^{\star}$ \\
\hline $\begin{array}{l}\text { Digital } \\
\text { Balloon } \\
\text { Weight balance }\end{array}$ & $\begin{array}{c}9(1.4) \\
111(16.8) \\
542(81.9)\end{array}$ & $\begin{array}{c}5(1 \cdot 5) \\
57(16 \cdot 6) \\
281(81.9)\end{array}$ & $\begin{array}{c}4(1 \cdot 3) \\
54(16.9) \\
261(81 \cdot 8)\end{array}$ & \\
\hline Section & & & & $0.95^{\star}$ \\
\hline $\begin{array}{l}\text { Corneal } \\
\text { Corneoscleral } \\
\text { Scleral }\end{array}$ & $\begin{array}{c}12(1 \cdot 8) \\
643(97 \cdot 1) \\
7(1 \cdot 1)\end{array}$ & $\begin{array}{c}6(1 \cdot 7) \\
333(97 \cdot 1) \\
4(1 \cdot 2)\end{array}$ & $\begin{array}{c}6(1 \cdot 9) \\
310(97 \cdot 2) \\
3(0.9)\end{array}$ & \\
\hline Extraction & & & & $0.45^{\star}$ \\
\hline $\begin{array}{l}\text { Cryo } \\
\text { Forceps } \\
\text { Tumbling }\end{array}$ & $\begin{array}{c}640(96 \cdot 7) \\
3(0.5) \\
19(2 \cdot 9)\end{array}$ & $\begin{array}{c}335(97 \cdot 9) \\
2(0 \cdot 6) \\
6(1 \cdot 7)\end{array}$ & $\begin{array}{c}305(95 \cdot 6) \\
1(0 \cdot 3) \\
13(4 \cdot 1)\end{array}$ & \\
\hline Solutions & & & & \\
\hline $\begin{array}{l}\text { Viscoelastic } \\
\text { Ringer's lactate } \\
\text { Balanced salt solution } \\
\text { Intraocular pilocarpine solution } \\
\text { Sheet's intraocular lens glide }\end{array}$ & $\begin{aligned} 52(7 \cdot 9) \\
148(22 \cdot 4) \\
6(0 \cdot 9) \\
84(12 \cdot 7) \\
204(30 \cdot 8)\end{aligned}$ & $\begin{array}{r}49(14 \cdot 3) \\
75(21 \cdot 9) \\
3(0 \cdot 9) \\
72(21 \cdot 0) \\
204(59 \cdot 5)\end{array}$ & $\begin{array}{c}3(0 \cdot 9) \\
73(22 \cdot 9) \\
3(0 \cdot 9) \\
12(3 \cdot 8) \\
0\end{array}$ & $\begin{array}{r}<0.01 \dagger \\
0.81^{\star} \\
1.00 \dagger \\
<0.01^{\star}\end{array}$ \\
\hline
\end{tabular}

${ }^{\star} \chi^{2}$ with continuity correction. $\nmid$ Fisher's exact test.

Table 5 Surgical complications by study groups

\begin{tabular}{|c|c|c|c|c|}
\hline & $\begin{array}{l}\text { Study total }(n=662) \\
n(\%)\end{array}$ & $\begin{array}{l}\operatorname{IOL}(n=343) \\
n(\%)\end{array}$ & $\begin{array}{l}\text { No IOL }(n=319) \\
n(\%)\end{array}$ & $\stackrel{p}{\text { Value }^{\star}}$ \\
\hline $\begin{array}{l}\text { Implantation not attempted } \\
\text { Aborted implantations }\end{array}$ & & $\begin{array}{l}6(1 \cdot 7) \\
6(1 \cdot 7)\end{array}$ & & \\
\hline $\begin{array}{l}\text { Patients with complications } \\
\text { Iris dialysis } \\
\text { Capsular rupture } \\
\text { Vitreous loss (all) } \\
\text { Unplanned ECCE }\end{array}$ & $\begin{array}{l}103(15 \cdot 6) \\
9(1 \cdot 4) \\
40(6 \cdot 0) \\
51(7 \cdot 7) \\
13(2 \cdot 0)\end{array}$ & $\begin{array}{l}58(16 \cdot 9) \\
5(1 \cdot 5) \\
21(6 \cdot 1) \\
30(8 \cdot 7) \\
7(2 \cdot 0)\end{array}$ & $\begin{array}{l}45(14 \cdot 1) \\
4(1 \cdot 3) \\
19(6 \cdot 0) \\
21(6 \cdot 6) \\
6(1 \cdot 9)\end{array}$ & $\begin{array}{l}0.37 \\
0.91 \\
0.95 \\
0.37 \\
0.89\end{array}$ \\
\hline
\end{tabular}

${ }^{\star} \chi^{2}$ with continuity correction.

\section{VISUAL ASSESSMENTS}

All visual assessments were performed using standard $60 \mathrm{~W} \times 2$ illuminated vision boxes with Snellen optotypes at 6 metres. At the 6 week follow up patients were tested with best possible spherical and cylindrical correction (BPC). A second level of vision, the patients' best available correction (BAC), was tested at 1 and 2 year follow up examinations. For the BAC the IOL cases were tested without correction and no IOL (aphakic) cases were tested with +10 spherical correction.

\section{IMAGE DOCUMENTATION}

The Topcon IMAGEnet digital imaging system Cellsoft Version 3.5 was used for image documentation and analysis. Patient identification was secured with image ID portraits taken preoperatively and at each follow up examination using a Canon RC-260 ion still video camera and transferred to the computer. In addition, a standard portrait identification for patient ID card and folder was made using a Polaroid mini-portrait camera.

Image documentation of the anterior segment and corneal endothelium cells was secured with a Sony XC77CE single chip high resolution black and white video camera mounted on a Topcon SL-7F slit-lamp. The anterior segment images were taken with the slit-lamp set at $10 \times$ magnification. One or more images were captured using the flash acquisition menu of the software program and were subsequently kept for review together with the ID image.

One image is selected and stored together with the ID image on the $200 \mathrm{MB}$ hard disk of the computer. Corneal endothelial cell images (each image includes about 500 cells) were taken using a non-contact specular microscope attached to a SL-7F photo slit-lamp set at $25 \times$ magnification (total image magnification $280 \times$ ). Several images were reviewed before the best image was saved on the hard disk. The images were recalled later and analysis was performed with the automated cell analysis program. Each analysis included about 100 cells. At the end of the day the image files were copied to $940 \mathrm{MB}$ optical cartridges and stored as backup. The same routine of image documentation was done for the preoperative examination and the three scheduled follow up examinations.

\section{ETHICAL CONSIDERATIONS}

The study protocol was reviewed and approved by the local ethics or other appropriate committee of each centre and the coordinating institution, according to guidelines set out in the Helsinki Declaration. Each patient was given an appropriate explanation of details of 
Table 6 Postoperative complications and reactions at 6 weeks of follow up

\begin{tabular}{lllll}
\hline & $\begin{array}{l}\text { Study total }(n=643) \\
n(\%)\end{array}$ & $\begin{array}{l}\text { IOL }(n=334) \\
n(\%)\end{array}$ & $\begin{array}{l}\text { No IOL (n=309) } \\
n(\%)\end{array}$ & $\begin{array}{l}p \\
\text { Value }\end{array}$ \\
\hline Iritis & $12(1 \cdot 9)$ & $11(3 \cdot 0)$ & $1(0 \cdot 3)$ & $0 \cdot 01$ \\
Hyphaema & $9(1 \cdot 4)$ & $6(1 \cdot 8)$ & $3(1 \cdot 0)$ & $0 \cdot 30$ \\
Pupil block glaucoma & $3(0 \cdot 5)$ & $3(0 \cdot 9)$ & 0 & $0 \cdot 10$ \\
Iris prolapse & $5(0 \cdot 8)$ & $3(0 \cdot 9)$ & $2(0 \cdot 6)$ & $1 \cdot 00$ \\
Retinal detachment & $2(0 \cdot 3)$ & 0 & $2(0 \cdot 6)$ & $0 \cdot 23$ \\
Total complications & $31(4 \cdot 8)$ & $23(6.9)$ & $8(2 \cdot 6)$ & $0 \cdot 02$ \\
\hline
\end{tabular}

${ }^{\star} \chi^{2}$ with continuity correction and Fisher's exact test.

the study according to guidelines set out in the study protocol. A signed consent (signature or thumbprint) was secured from each participant. An international committee reviewed the data for quality and consistency and based on predefined stopping rules monitored the adverse reactions.

DATA MANAGEMENT AND ANALYSIS

Patient registration, basic documentation, and management of patient flow were secured with a dedicated database. The daily coordination and monitoring of the study was undertaken by a regional office that reviewed and collated the data of the participating centres. Each centre was visited three to four times a year by the project coordinator and all image documentation was reviewed and cross checked with the database using a grid system. Multiple logistic regression analysis using the SPSS $\mathrm{PC}+$ version 4.0 was done to determine possible association of preoperative patient characteristics, surgical procedure, intraoperative surgical complications, and operative complications to visual outcome. Variables that demonstrated a significant effect on outcome were included in a regression model to evaluate their relative risks. EPI INFO Version 5.01b was used for generation of frequency distributions, $2 \times 2$ tables, and means. Parametric and non-parametric statistical analyses were used based on the distribution of the data. Analysis of continuous variables between two groups was tested using two sample Student's $t$ test for normally distributed data and analysis of variance (ANOVA) for differences of more than two groups. For nonparametric data the Wilcoxon rank sum test was used for comparisons between two groups and the Kruskal-Wallis test was used for analysis of difference between more than two groups. Categorical variables were tested with the $\chi^{2}$ test with continuity correction or Fisher's exact test. The data were analysed on basis of intention to treat.

\section{STUDY POPULATION}

The study population consisted of 662 cases (343 men and 319 women); 318 (48.0\%) patients were bilaterally blind (visual acuity less than $3 / 60$ in better eye). Tables 2 and 3 shows mean age, intraocular pressures, and corneal endothelial cell densities by participating centres and study groups respectively. Except for a statistically significant difference in mean intraocular pressure between participating centres there was no significant difference between mean age or corneal endothelial cell counts between centres or between study groups.

\section{Results}

A total of 662 surgical procedures were performed with intracapsular cataract surgery between January 1993 and June 1994. No lens extraction was aborted because of complications: $343(52 \%)$ patients were randomised to IOL and $319(48 \%)$ patients were randomised to no IOL. Thirteen surgeons performed an average of 51 (SD 7.4) surgical procedures. On average each surgeon performed equal numbers of the two types of operations.

There was no significant difference of the surgical routines used between the study groups (Table 4). Of the 343 eyes randomised to the IOL group 331 (97\%) IOLs were successfully

Table 7 Mean corneal endothelium cell density and percentage cell loss by study group at 6 week follow up

\begin{tabular}{|c|c|c|c|c|c|c|c|}
\hline & \multicolumn{4}{|c|}{ Cell density $\left(\mathrm{cell} / \mathrm{mm}^{2}\right)$} & \multicolumn{3}{|l|}{ Cell loss (\%) } \\
\hline & \multicolumn{2}{|l|}{$I O L$} & \multicolumn{2}{|l|}{ No IOL } & \multirow{2}{*}{$\frac{I O L}{\text { Mean }(S D)}$} & \multirow{2}{*}{$\frac{\text { No IOL }}{\text { Mean (SD) }}$} & \multirow{2}{*}{$\stackrel{p}{\text { Value }}^{\star}$} \\
\hline & Mean (SD) & Range & Mean $(S D)$ & Range & & & \\
\hline Preoperative & $\begin{array}{l}\mathrm{n}=333 \\
2748(373)\end{array}$ & $1408-3567$ & $\begin{array}{l}\mathrm{n}=307 \\
2755(341)\end{array}$ & $1502-3629$ & & & \\
\hline Postoperative & $\mathrm{n}=333$ & & & & & & \\
\hline $\begin{array}{l}\text { All } \\
\text { Uncomplicated }\end{array}$ & $\begin{array}{l}2235(468) \\
n=275\end{array}$ & $573-3431$ & $\begin{array}{l}2308(446) \\
n=266\end{array}$ & $852-3197$ & $18 \cdot 5(13 \cdot 6)$ & $16 \cdot 1(12 \cdot 5)$ & 0.05 \\
\hline surgery & $2243(469)$ & $573-3431$ & $2327(422)$ & $1141-3197$ & $18 \cdot 1(13 \cdot 5)$ & $15 \cdot 5(11 \cdot 4)$ & 0.05 \\
\hline $\begin{array}{l}\text { Complicated } \\
\text { surgery }\end{array}$ & $\begin{array}{l}n=58 \\
2203(469)\end{array}$ & $673-3225$ & $\begin{array}{l}\mathrm{n}=41 \\
2190(567)\end{array}$ & $852-2918$ & $20.5(14.0)$ & $20.4(17 \cdot 4)$ & 0.97 \\
\hline
\end{tabular}

ॠTwo sample Student's $t$ test and Kruskal-Wallis test.

Table 8 Mean cell density and percentage cell loss by complication at 6 week follow up

\begin{tabular}{|c|c|c|c|c|c|c|c|}
\hline & \multicolumn{4}{|c|}{ Postoperative cell density $\left(\mathrm{cell} / \mathrm{mm}^{2}\right)$} & \multicolumn{3}{|c|}{ Postoperative cell loss (\%) } \\
\hline & \multicolumn{2}{|l|}{ Complications } & \multicolumn{2}{|c|}{ No complications } & \multirow{2}{*}{$\begin{array}{l}\text { Complications } \\
\text { Mean (SD) }\end{array}$} & \multirow{2}{*}{$\frac{\text { No complications }}{\text { Mean }(S D)}$} & \multirow[b]{2}{*}{ Value $^{\star}$} \\
\hline & Mean (SD) & Range & Mean $(S D)$ & Range & & & \\
\hline $\begin{array}{l}\text { Intraoperative } \\
\text { Postoperative }\end{array}$ & $\begin{array}{l}n=98 \\
2197(511) \\
n=31\end{array}$ & 673-3225 & $\begin{array}{l}\mathrm{n}=542 \\
2284(448) \\
\mathrm{n}=609\end{array}$ & 573-3431 & $20 \cdot 5(15 \cdot 4)$ & $16 \cdot 9(12 \cdot 6)$ & 0.05 \\
\hline & $2224(410)$ & $1371-3267$ & $2273(461)$ & $573-3431$ & $17 \cdot 2(10 \cdot 9)$ & $17 \cdot 4(13 \cdot 3)$ & 0.92 \\
\hline
\end{tabular}

`Two sample Student's $t$ test and Kruskal-Wallis test. 


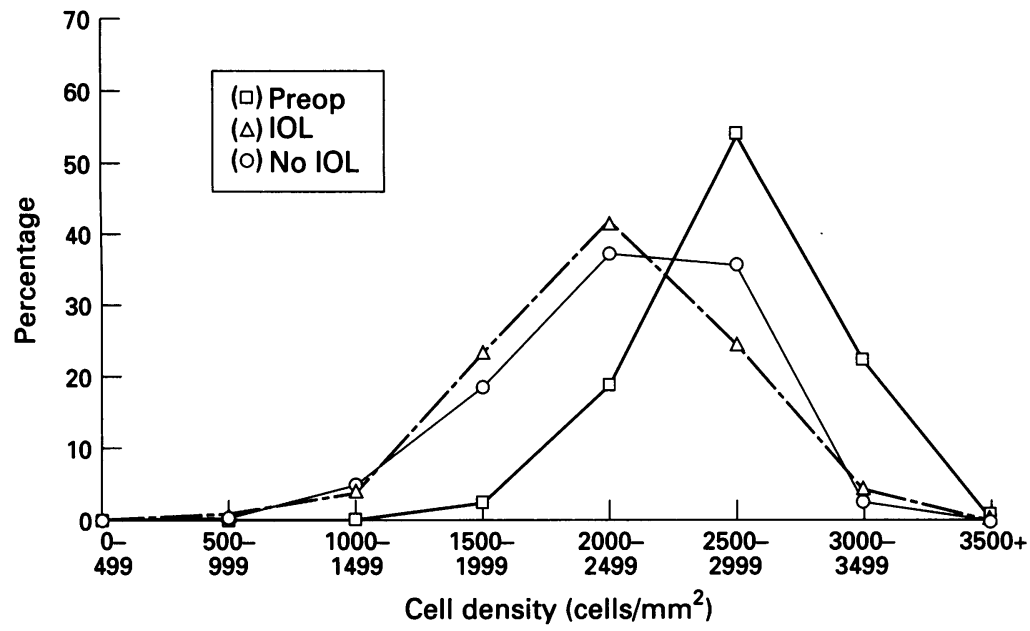

Figure 1 Preoperative and postoperative distribution of corneal endothelium cell density.

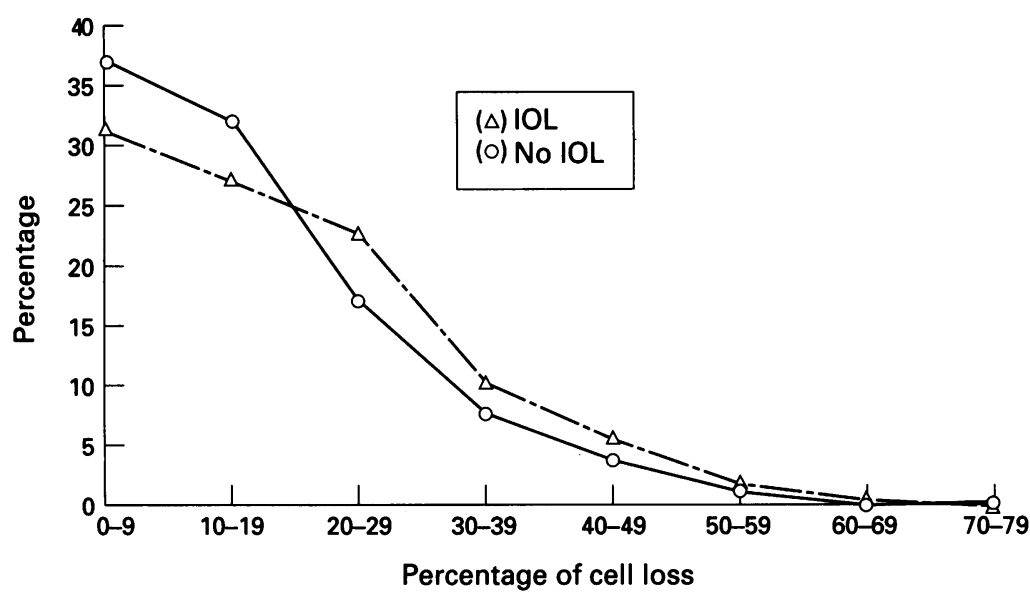

Figure 2 Percentage of corneal endothelium cell loss 6 weeks after surgery.

implanted. In six $(1 \cdot 7 \%)$ complicated operations IOL implantation was not attempted because of a surgically related complication. In six $(1 \cdot 7 \%)$ procedures lens implant was attempted but aborted because of a complication during the attempt of IOL insertion (Table 5). Table 5 gives the rate of surgical complications. Vitreous loss was the most frequent surgical complication followed by plain capsular rupture, unplanned extracapsular extraction, and iris dialysis. There was no significant difference in the complication rates between study groups.

Of the 662 operations included in this first series 643 patients had been examined at the first follow up schedule (IOL 333, no IOL 310). Three cases $(0.5 \%)$, all in the IOL group, were lost to follow up because of death; $16(2 \cdot 4 \%)$ cases were still not examined at the
6 week follow up schedule. At 6 weeks of follow up $31(4 \cdot 8 \%)$ immediate and short term postoperative complications had been reported (Table 6). The cumulative rate of postoperative complications was significantly higher in the IOL group ( $p=0.01)$ owing to moderate iritis that needed prolonged use of local steroids. Moderate iritis represented $38.7 \%$ of total complications, followed by hyphaema $(29.0 \%)$. Two patients, both in the no IOL group, developed retinal detachment. The relative risk of postoperative complication after lens implantation was $2 \cdot 7(95 \% \mathrm{CI}=1 \cdot 2-5 \cdot 9)$ compared with ICCE without implantation of an AC lens (Table 6).

Of the 641 slit-lamp microscopic observations of study eyes 128 eyes (20\%) showed ovaling of the pupil. This was the only observation that showed a statistically significant difference between groups (relative risk $(R R)=4 \cdot 0,95 \% C I=2 \cdot 5-6 \cdot 5)$. One patient had dislocation of the IOL $(0.3 \%)$ with the inferior haptique of the IOL luxated behind the iris. At 6 weeks mean intraocular pressure was $12 \mathrm{~mm} \mathrm{Hg}$ in both groups (range 4-21). Two patients in the IOL group had a transient pressure rise, one patient in the immediate postoperative period, the other at 1 month. Three patients $(1.0 \%$ of IOL cases) needed secondary surgical intervention because of acute pupil block glaucoma.

Tables 7 and 8 summarise the endothelial cell data between study groups at 6 weeks of follow up. A total of $640(96.6 \%)$ corneal endothelial cell images were available for analysis. Mean cell loss was $17 \cdot 4 \%$ (SD 13.4). The IOL group had a $2 \cdot 5 \%$ greater cell loss than the no IOL group $(p=0.05)$. Patients with intraoperative complications had a significantly higher percentage cell loss compared with those without complications. There was no difference between study groups. Only four patients had cell counts less than 1000. The mean corneal endothelial cell loss in these patients was $45 \%$ (Figs 1 and 2).

Six weeks after surgery we found that $89 \%$ had normal vision using WHO categories (Table 9). There was no significant difference between study groups. The effect of age, sex, preoperative vision, preoperative intraocular pressure, endothelial cell densities, surgical procedure, surgical complications, participating centre, and type of surgery on visual outcome were examined with multiple logistic regression. Only exposure to intraoperative and postoperative surgical complications was

Table 9 Preoperative visual acuity of induction eye and distribution by study group at 6 week follow up

\begin{tabular}{|c|c|c|c|c|c|c|c|c|c|c|c|c|}
\hline \multicolumn{3}{|l|}{ Preoperative } & \multirow{2}{*}{\multicolumn{5}{|c|}{ Postoperative IOL WHO category }} & \multirow{2}{*}{\multicolumn{5}{|c|}{ No IOL WHO category }} \\
\hline \multirow{2}{*}{$\begin{array}{l}\text { Visual acuity } \\
\text { inclusion eye }\end{array}$} & \multirow{2}{*}{\multicolumn{2}{|c|}{$\begin{array}{l}W H O^{\star} \\
\text { category }\end{array}$}} & & & & & & & & & & \\
\hline & & & 0 & 1 & 2 & 3 & $4-5$ & 0 & 1 & 2 & 3 & $4-5$ \\
\hline $\begin{array}{l}6 / 6-6 / 18 \\
6 / 24-6 / 60 \\
3 / 60 \\
1 / 60 \\
\text { Perception of light } \\
\text { No perception of light } \\
\text { All }\end{array}$ & $\begin{array}{l}0 \\
1 \\
2 \\
3 \\
4 \\
5 \\
0-5\end{array}$ & $\begin{array}{l}\bullet \\
31(4 \cdot 8 \%) \\
58(9 \cdot 0 \%) \\
212(33 \%) \\
342(53 \cdot 2 \%) \\
\bullet \\
643\end{array}$ & $\begin{array}{l}\bullet \\
89 \cdot 5 \% \\
87 \cdot 1 \% \\
86 \cdot 3 \% \\
89 \cdot 0 \% \\
\bullet \cdot 0 \\
88 \cdot 0 \%\end{array}$ & $\begin{array}{r}\bullet \\
10 \cdot 5 \% \\
12 \cdot 9 \% \\
12 \cdot 7 \% \\
9 \cdot 9 \% \\
\bullet \\
11 \cdot 1 \%\end{array}$ & $\begin{array}{l}: \\
: \\
0.5 \% \\
0.3 \%\end{array}$ & $\begin{array}{l}: \\
\bullet \\
1 \cdot 0 \% \\
0 \cdot 5 \% \\
0 \cdot 6 \%\end{array}$ & : & $\begin{array}{l}\bullet \\
91 \cdot 7 \% \\
88 \cdot 9 \% \\
90 \cdot 9 \% \\
89 \cdot 4 \% \\
\bullet \\
90 \%\end{array}$ & $\begin{array}{l}\bullet \\
8 \cdot 3 \% \\
7 \cdot 4 \% \\
6 \cdot 4 \% \\
8 \cdot 1 \% \\
7 \cdot 4 \%\end{array}$ & $\begin{array}{l}\bullet \\
\bullet \\
\bullet \\
0 \cdot 6 \% \\
\bullet \\
0 \cdot 3 \%\end{array}$ & $\begin{array}{l}\bullet \\
3 \cdot 7 \% \\
1 \cdot 8 \% \\
1 \cdot 9 \% \\
1 \cdot 9 \%\end{array}$ & $\begin{array}{l}\bullet \\
: \\
0.9 \% \\
: \\
0.3 \%\end{array}$ \\
\hline
\end{tabular}

^WHO categories BPC operated eye; $1-5=$ principal outcome: poor vision $<6 / 18$ with best possible correction. 
Table 10 Age and sex adjusted risk factors for poor visual outcome ${ }^{\star} 6$ weeks after surgery

\begin{tabular}{llll}
\hline & Odds ratio & $95 \%$ CI† & $p$ Value \\
\hline Intraoperative complications & 3.1 & $1.7-5.6$ & $<0.01$ \\
Postoperative complications & 4.4 & $1.8-10.2$ & $<0.01$
\end{tabular}

${ }^{\star}$ Visual acuity $<6 / 18 . \dagger \mathrm{CI}=$ confidence interval. $N=643$.

related to increased risk of poor vision (Table 10).

\section{Discussion}

The visual outcomes were comparable with the results of intracapsular cataract surgery in this setting. ${ }^{22} 23$ The overall rate of postoperative complications was higher in the IOL group $(6.9 \%)$. This was mainly due to a higher rate of persistent mild iritis $(3.0 \%)$ needing prolonged use of local steroids. This finding did not qualify as a reason for stopping the trial and is comparable with that reported in a recent survey of short term outcomes of cataract surgery in the UK. ${ }^{24}$ Despite our efforts to reduce variability of surgical complications with introduction of minimum entry criteria for participating surgeons we found that one centre had a considerable variability of vitreous loss between surgeons. Despite this caveat there was no significant difference in intraoperative surgical complications between the study groups. In the analysis of corneal cell data we found a small, but statistically significant, greater mean cell loss in the IOL group $(p=0.05)$. This finding is probably related to the increased surgical manipulation of the IOL insertion. There was only a relatively modest increase in mean cell loss in the group of complicated surgeries $(2.6 \%)$ compared with the non complicated cases. There was no difference between study groups. In the only randomised clinical study with cell data reported, ${ }^{25}$ a group of 74 patients with plain ICCE without IOL implantation had a mean cell loss of $10 \cdot 7 \%$ compared with our ICCE no IOL group of $16 \cdot 1 \%$. The ECCE group $(n=74)$ had a comparable rate of cell loss to our IOL group.

We have reported an interim analysis of the short term outcomes of the only multicentre study of cataract surgery in south Asia. Based on the analysis from this study, which includes surgeons with a wide variability of surgical skills, the introduction of AC IOL does not significantly increase the rate of intraoperative surgical complications. Although small in number and for the majority cases of mild iritis, we did find a significant increase in postoperative reactions in the IOL group compared with the no IOL group. However, this difference is not reflected in the short term visual outcome between groups. The distribution of visual outcomes and corneal endothelial cell loss is similar in both groups at the 6 week follow up. Analysis of 1 and 2 year follow up should give definite conclusions on long term visual outcomes and corneal survival.

The development of protocol has been undertaken in consultation with the Oxford Cataract Treatment and Evaluation team (OCTET), Oxford Eye Hospital, University of Oxford, the
Epidemiology Unit of the International Centre for Eye Health (ICEH), Institute of Ophthalmology, University of London and the Centre for Intraocular Lens Research, Storm Eye Institute, Medical University of South Carolina.

The SACMS would like to express its appreciation to Alcon International for its generous donation of intraocular lenses, to the Visitec Corporation for donation of lens glides, and to Topcon Europe for its technical support.

The SACMS is supported financially by the Norwegian The SACMS is supported financially by the Norwegian
Universities Council's Committee for Development Research Universities Council's Committee for Development Research
and Education (NUFU), the Norwegian Research Foundation and Education (NUFU), the Norwegian Research Foundation and Faculty of Medicine, University of Tromsø (UiTø), Norway.

A special thanks to Ruth Bjørn and Bjørg Hunstad at the Institute of Community Medicine, University of Tromsø for their dedication and hard work in relation to project administration.

1 Pizarello L. Intraocular lens use in developing countries. Ophthalmic Surg 1989; 20: 240.

2 Pizarello L, Ellwin LB. The choice of cataract surgical techniques in developing nations: operations research considerations. Int Ophthalmol 1990; 14: 147-54.

3 Young PW, Schwab L. Intraocular lens implantation in developing countries: an ophthalmic surgical dilemma Ophthalmic Surg 1989; 20: 241-4.

4 Khosla PK. Community ophthalmology: an Indian perspective. New Delhi: Current Scientific Literature, 1992: 113-20.

5 Apple DJ, Solomon KD, Tetz MR, Assia EI, Holland EY, Legler UFC, et al. Major review: posterior capsule opacification. Surv Ophthalmol 1992; 37: 73-116.

6 Civerchia L, Apoorvananda SW, Natchiar G, Balent A Ramakriahnan $R$, Green D. Intraocular lens implantation in rural India. Ophthalmic Surg 1993; 24: 648-52.

7 Wright PL, Wilkinson CP, Hal D, Balyeat MD, Popham J, Reinke $M$. Angiographic cystoid macular oedema after posterior chamber lens implantation. Arch Ophthalmol 1988; 106: 740-4.

8 Kraff CM, Sanders DR, Jampol LM, Lieberman HL. Effect of primary capsulotomy with extracapsular surgery on the incidence of pseudophakic cystoide macular oedema. $A m$ f Ophthalmol 1984; 98: 166-70.

9 Javitt JC, Tielch JM, Canner JK, Kolb MM, Sommer A Steinberg EP. National outcomes of cataract extraction. Increased risk of retinal complications associated with Nd:YAG laser caposulotomy. Ophthalmology 1992; 99: Nd:YAG

10 World Health Organisation. Available data on blindness (update 1994). Geneva: WHO/PBL/94.38.

11 World Health Organisation. Global data on blindness - an update. Geneva: WHO/PBL/94.40.

12 Apple DJ, Brems RN, Park RB, Norman DK, Hansen SO, Tetz MR, et al. Anterior chamber lenses. Part I: Complications and pathology and a review of designs. $\mathcal{f}$ Cataract Refract Surg 1987; 13: 1257-74.

13 Apple DJ, Hansen SO, Richards SC, Ellis GW, Kavka-VanNorman D, Tetz MR, et al. Anterior chamber lenses. Part II: A laboratory study. $\mathcal{F}$ Cataract Refract Surg 1987; 13: 1275-89.

14 Lim ES, Apple DJ, Tsai JC, Morgan RC, Wasserman D, Assia EL. An analysis of flexible anterior chamber lenses with special reference to the normalized rate of lens explantation. Ophthalmology 1991; 98: 243-6.

15 World Health Organisation. Report of the consultation on the use of intraocular lenses in cataract surgery in developing countries. Geneva: WHO, WHO/PBL/91.1.

16 Auffarth UG, Wesendahl TA, Brown SJ, Apple DJ. Are there acceptable anterior chamber intraocular lenses for clinical use in the 1990s? An analysis of 4104 explanted clinical use in the 1990s? An analysis of 4104 explanted
anterior chamber intraocular lenses. Ophthalmology 1994; 101: 1913-22.

17 Hassan TS, Kaz SH, Sugar A, Meyer RF. Implantation of Kelman-style, open-loop anterior chamber lenses during keratoplasty for aphakic and pseudophakic bullous keratopathy: a comparison with iris-sutured posterior chamber lenses. Ophthalmology 1991; 98: 875-80.

18 Koenig SB, McDermott ML, Hyndiuk RA, Penetrating keratoplasty and intraocular lens exchange for pseudophakic bullous keratopathy associated with a closed-loop phakic bullous keratopathy associated with a closed-loop 108: $43-8$.

19 Williamson DE. Incidence of cystoid macular edema and retinal detachment after intracapsular cataract extraction and a modern anterior chamber IOL. Boston: ASCRS Symposium on Cataract, IOL and Refractive Surgery, April 8, 1991.

20 Vogel M, Behrens-Baumann W, Petersen J, Quentin CD, Hilgers R, Kron $R$, et al. Vergleich der Komplikationen nach intra- und extrakapsularer Kataraktextraktionen mit Linseimplantation: Ergebnisse einer prospektiven, randomiisierten, klinischen Studie. Klin Monatsbl Augenheilkd 1993; 203: 43-52.

21 Mehra V, Minassian DC. A rapid method of grading cataract in epidemiological studies and eye surveys. $\mathrm{Br} \mathscr{F}$ Ophthalmol 1988; 72: 801-3.

22 Reidy A, Mehra V, Minassian D, Mahashabde S. Outcome of cataract surgery in central India: a longitudinal followup study. Br fOphthalmol 1991; 75: 102-5.

23 Henning A, Shrestha SP, Foster A. Results and evaluation of high volume intracapsular cataract surgery in Nepal. Acta Ophthalmol 1992; 70: 402-6.

24 Desai $P$. The national cataract surgery survey. II Clinical outcomes. Eye 1993; 7: 489-94.

25 Cheng $H$, McPherson $K$, Bron AJ. I. Cataract surgery: interim results and complications of a randomised con trolled trial. Brf Ophthalmol 1986; 70: 402-10. 
Appendix

PARTICIPANTS

Investigators: T Snellingen, ${ }^{4} 6 \mathrm{~S}$ Gupta, ${ }^{3} \mathrm{~F}$ Huq, ${ }^{2} \mathrm{~J} \mathrm{~K}$ Shrestha, ${ }^{1} \mathrm{R}$ Husain, ${ }^{2} \mathrm{~S}$ Koirala, ${ }^{1} \mathrm{G} N$ Rao.

Surgeons: S Anwar, ${ }^{2}$ R K Adhikari, ${ }^{7}$ S Basti, ${ }^{3}$ S S Gupta, ${ }^{3}$ Dhakal, ${ }^{7}$ F Huq, ${ }^{2}$ S Kutubi, ${ }^{2} \mathrm{~K}$ M Reddy, ${ }^{3} \mathrm{~J}$ K Shrestha, ${ }^{1} \mathrm{C}$ Tenzing, ${ }^{3} \mathrm{M}$ Vagh. ${ }^{3}$

SACMS technical staff: M Begum, ${ }^{2} \mathrm{~J}$ Dahal, ${ }^{1} \mathrm{~S}$ Laxmi, ${ }^{3}$

S Reddy, ${ }^{3}$ R Saha, ${ }^{2}$ S Sharma. ${ }^{1}$

Administrators and field coordinators: $\mathrm{R}$ Babu, ${ }^{3} \mathrm{M}$

Gharti, ${ }^{6}$ E Hoque. ${ }^{2}$

Computer consultant: E Kureghian, ${ }^{12} \mathrm{~S}$ Upadhyay.

Principal programme administrator: $\mathrm{H}$ B Gurung

Review committee: D J Apple, ${ }^{10}$ E Arnesen, ${ }^{5}$ H Cheng, ${ }^{9}$ E G Olsen, ${ }^{11} \mathrm{M}$ Vogel. ${ }^{8}$

1 Institute of Medicine, Tribhuvan University Teaching Hospital, Kathmandu, Nepal.
2 Institute of Community Ophthalmology, University of Chittagong, Bangladesh.

3 LV Prasad Eye Institute, Banjara Hills, Hyderabad, India 4 Health Systems Research, Institute of Community Medicine, University of Tromsø, Norway.

5 Epidemiology and Medical Statistics, Institute of Community Medicine, University of Tromsø, Norway.

6 SACMS Regional Office, Institute of Medicine, Tribhuvan University Teaching Hospital, Kathmandu, Nepal.

7 Mid-Western Eye Care Programme, Nepal Netra Jyothi Sangh, Dang, Nepal.

8 Department of Ophthalmology, Universitatsklinik, Gottingen, Germany.

9 Oxford Eye Hospital, University of Oxford, UK

10 Center for Intraocular Lens Research, Medical University of South Carolina, Charleston, SC, USA.

11 Institute of Clinical Medicine, University of Tromsø, Tromsø, Norway.

12 South Ealing, London, UK. 